\title{
PHILOSOPHICAL AwAKENING
}

\author{
DESPERTAR FILOSÓFICO \\ Victor J. Krebs \\ DOI 10.26754/ojs_arif/a.rif.201924164
}

\begin{abstract}
This paper is about (i) our traditional resistance to feeling as constitutive of the philosophical task, and (ii) the power of aesthetics to enable ethics. It claims that feeling is necessary for meaning and value. It is argued, further, that aesthetic experience, and the aesthetic in general, have the power to wake us up from our usual existential sleep or numbness. Because the grammar of aesthetic language involves self-exposure and self-commitment, we suggest, in rejecting the sensible, we may be disavowing the inevitable emotional engagement in all human communication and evading the difficulty of the vulnerability necessary for the real task of philosophy.
\end{abstract}

KEYWORDS: aesthetics, aesthetic experience, ethics, the task of philosophy, existential sleep, emotional engagement, human communication.

\section{RESUMEN}

Este artículo trata sobre (i) nuestra resistencia tradicional al sentimiento como constitutivo de la tarea filosófica; y (ii) sobre el poder de la estética para permitir la ética. Se afirma que el sentimiento es necesario para el significado y el valor. Se argumenta, además, que la experiencia estética, y la estética en general, tienen el poder de despertarnos de nuestro sueño o entumecimiento existencial habitual. Debido a que la gramática del lenguaje estético implica auto-exposición y auto-compromiso, sugerimos que al rechazar lo sensible, podemos estar rechazando el inevitable compromiso emocional en toda comunicación humana y evadiendo la dificultad de la vulnerabilidad necesaria para la verdadera tarea de la filosofía.

PALABRAS CLAVE: estética, experiencia estética, ética, la tarea de la filosofía, sueño existencial, compromiso existencial, comunicación humana. 


\section{PRELUDE}

Understanding a sentence is much more akin to understanding a theme in music that one may think.

(Wittgenstein (1968), §527)

The attitude we have in our academic culture towards aesthetics would make us think that it is something dangerous, especially because of the way we keep it -sometimes subtly and sometimes openly- marginalized from the scope of serious discussion, demanding that it satisfy criteria of validity and intellectual respectability that are alien to it, and ultimately alienating.

This attitude was present in the nineties in universities in the States, in their refusal to consider film, for instance, a legitimate object of study. Asked what he thought was the reason behind that rejection, Stanley Cavell responded:

"[one] answer to why film is resisted as a serious subject of study on the part of proper universities is often, that people are afraid in such a context, of the possibility of the frivolous [or] of their own pleasures, [...] perhaps of pleasures that seem to them low [...]." (Conant (1989), p. 68)

The same resistance against the aesthetic lives on today -perhaps not so much anymore towards film, which in the last few decades has gradually attained some academic respectability- but towards popular culture in general. It too is often rejected as an object of serious reflection, it seems, because of the same threats Cavell mentions, of shallowness and the implicit appeal to our passions. But, then as now, this attitude is, as Cavell put it, "merely philistine, intellectually and artistically indefensible.” (Conant (1989), p. 69)

\section{Aesthetic Power}

Commenting on Shakespeare's Tempest, Henry James (1988) wrote:

"[in] a masterpiece [the very act of that transcendental conjunction that occurs $[\ldots]$ in the $[$ artist], between $[\ldots]$ his lucid experience $[\ldots]$ and his aesthetic passion, becomes visible." (p. 433).

That transcendental conjunction, as James calls it, of lucidity and passion, is not exclusive, however, to the artistic creation. It is responsible, in general, for making things or events, people and actions important and morally relevant, able to define -or contribute to- the meaning of our lives. 
Rainer Maria Rilke (1989) describes just such a moment in these lines from his poem Archaic Torso of Apollo:

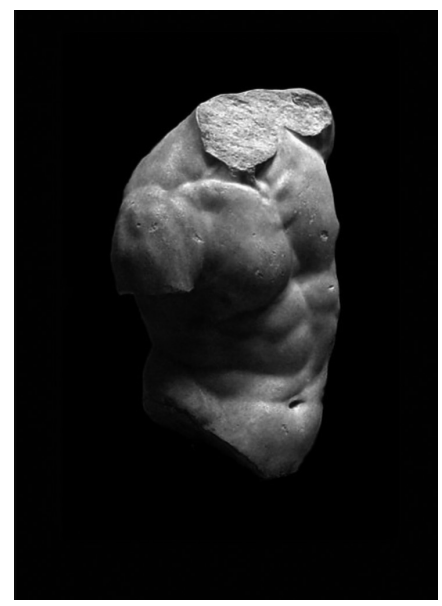

We cannot know his legendary head

With eyes like ripening fruit. And yet his torso

Is still suffused with brilliance from inside,

Like a lamp, in which his gaze, now turned to low,

gleams in all its power. Otherwise

the curved breast could not dazzle you so, nor could

a smile run through the placid hips and thighs

to that dark center where procreation flared.

Otherwise this stone would seem defaced beneath the translucent cascade of the shoulders

and would not glisten like a wild beast's fur:

would not, from all the borders of itself

burst like a star: for here there is no place

that does not see you. You must change your life. (p. 61)

From the lucidity of an aesthetic experience, an intimate passion can suddenly illuminate one's whole life, and stir the will with the need for change. Lucid experience and aesthetic passion, then, are elements of moral awakening in life.

Dante's (2012) account, in La Vita Nuova, of his first vision of Beatrice provides us with another example of that awakening. He writes:

At that time, truly, I say, the vital spirit, which dwells in the innermost chamber of the heart, started to tremble so powerfully that its disturbance reached all the way to the slightest of my pulses. And trembling it spoke these words: "Here is a god stronger than me; who will rule over me" (p. 3).

His experience insufflated by aesthetic passion got only gives rise, not only to a work of art, but also becomes a guide of life for Dante. Both cases bring to the fore something I would call the ethical power of the aesthetic, its influence, in other words, in promoting an ethical stance towards things.

The aesthetic transforms our rational understanding into a creative power, capable of infusing personal value and meaning to things. At its most elementary level the aesthetic makes us see things again, through feeling (delight or disgust, pleasure or displeasure, fear or awe, etc.) but it also draws an existential horizon from which our life can be grounded in our vital needs and desires. It transforms, in other words, the awareness of the subject into an ethical awakening. 
The word 'aesthetic' comes from the Greek $A \imath \sigma \theta \eta \sigma \iota \varsigma$, which means “sensible perception" and refers to the reception of the world through the bodily senses. The prejudice against the aesthetic is present in the resistance we are considering here to the serious use, for instance, of super-heroes and anti-heroes, celebrities like Madonna, Lady Gaga, or television series like Breaking Bad or Black Mirror, etc. The mere suggestion makes well established academics sometimes scowl.

That prejudice is a symptom of the traditional impetus to repress the bodily and its emotional engagement in the search for knowledge. It is as if we were convinced that "mere feeling," as John McDowell (1983) has put it, "could not contribute an experience in which the world reveals itself to us." (p. 16) That conviction -as another critic points out- "is an expression of the existential doubt that human beings can really get access to the world of things, can ever be said to truly know and value them" (Petts (2000), p. 62) through feeling.

This marginalization of the aesthetic is detrimental. It rips the ethical apart from experience, in order to define it instead with objective and rational arguments and ideologies. But, even worse, it threatens to make the world a foreign place, where it is eventually impossible to recognize or even find ourselves. Devoid of anything we can really feel as our own, disavowing our own interiority, we may begin to observe moral principles mechanically and to adopt attitudes that neither belong to us nor are faithful to ourselves.

\section{Knowing Through Feeling}

Now, knowing through feeling is not like knowing through the senses, which because they are common and shareable can ground our moral judgements. We can say to someone, "Touch this" (or smell or hear this) and -expecting the other's understanding-, continue our conversation on the basis of that common experience. But I can't tell you to feel what I am feeling, and then continue our conversation with the same assurance. 'Knowing through feeling' is not a mode of empirical, verifiable experience, that we can naturally go on to conceptualize or categorize intellectually. It is, rather, a mode of (inner?) perception, that brings what we are experiencing into a field of meaning, that not only makes it absolutely objective for us -something everybody would have to see (as Kant says of Beauty, for example)- but also, and at the same time, something that is intimate to me. The claim of knowledge it makes has the force of any rational knowing. As Cavell (1985a) puts it: 
$[F]$ eeling functions as a touchstone: the mark left on the stone is invisible to others, but the result is one of knowledge, or has the form of knowledge-it is directed to an object, the object has been tested, the result is one of conviction. This seems to me to suggest why one is anxious to communicate the experience of such objects. It is not merely that I want to tell you how it is with me, how I feel, in order to find sympathy or to be left alone, or for any other of the reasons for which one reveals one's feelings. It's rather that I want to tell you something I've seen, or heard, or realized, or come to understand, for the reasons for which such things are communicated (because it is news about a world we share, or could share). Only I find, that I can't tell you; and that makes it all the more urgent to tell you. I want to tell you because the knowledge, unshared, is a burden-not, perhaps, the way having a secret can be a burden, or being misunderstood; a little more like the way, perhaps, not being believed is a burden, or not being trusted. [...] It matters, there is a burden, because unless I can tell what I know, there is a suggestion (to myself as well) that I do not know. But I do-what I see is that (pointing to the object). But for that to communicate, you have to see it too. (p. 193)

We build the bridge to make these experiences shareable, with our words. My language must lead the other to that knowledge. And this means that if I want you to see what I see and share what I know, I will have to recreate for you -in my sentences and the experiences to which they appeal, in the words I stress, in their tempo, tone and rhythms even, in the associations they suggest, and the images they evoke- the same imaginative conditions under which I have experiences the object under the particular aspect I am trying to get you to see. A sentence as simple as: "Blue is the color of consciousness when it is caressed" does that job. But perhaps more pertinently, the following example, from "A Matter of Meaning it," where Cavell (1985b) is articulating his experience of Anthony Caro's sculptures, clearly exemplifies what I mean:
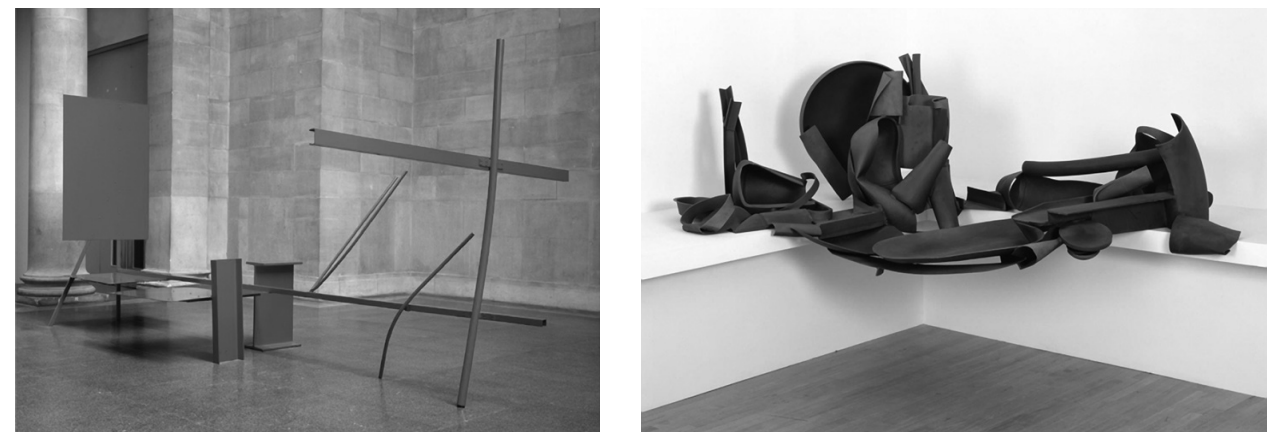
Caro uses steel rods and beams and sheets which he does not work (e.g., bend or twist) but rather, one could say, places. I had thought that a piece of sculpture had the coherence of a natural object, that it was what I wish to call spatially closed or spatially continuous (or consisted of a group of objects of such coherence); but a Caro may be open and discontinuous, one of its parts not an outgrowth from another, nor even joined or connected with another so much as it is juxtaposed to it, or an inflection from it. I had thought a piece of sculpture stood on a base (or crouched in a pediment, etc.) and rose; but a Caro rests on the raw ground and some do not so much rise as spread or reach or open.
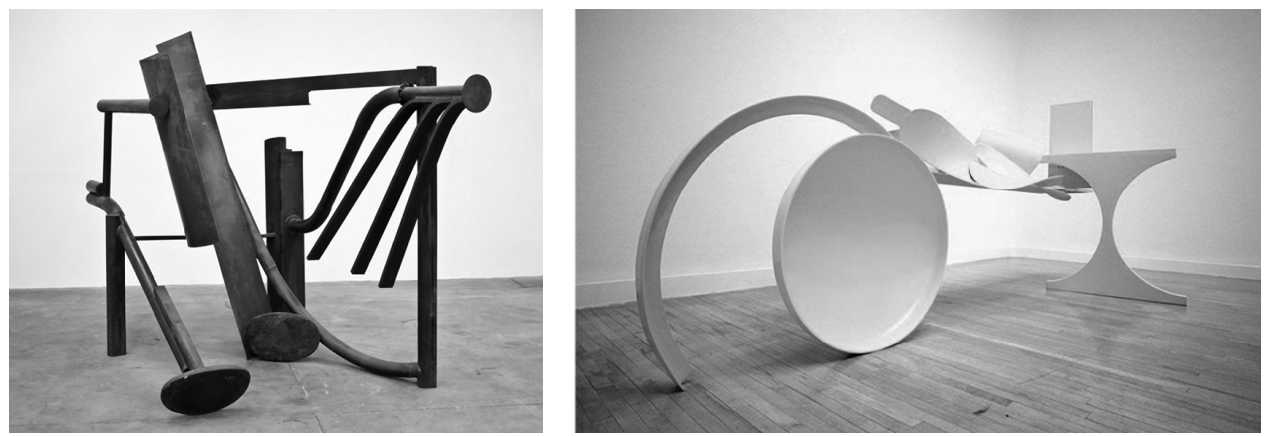

I had heard that sculpture used to be painted, and took it as a matter of fashion or taste that it no longer was [...]; Caro paints his pieces, but not only is this not an external or additional fact about them, it creates objects about which I wish to say they are not painted, or not colored: they have color not the way, say, cabinets or walls do, but the way grass and soil do [...] It is almost as though the color helps de-materialize its supporting object. One might wish to say they are weightless, but that would not mean that these massively heavy materials seem light, but, more surprisingly, neither light nor heavy, resistant to the concept of weight altogether - as they are resistant to the concept of size; they seem neither large nor small. [...] They are no longer things. (pp. 217-218)
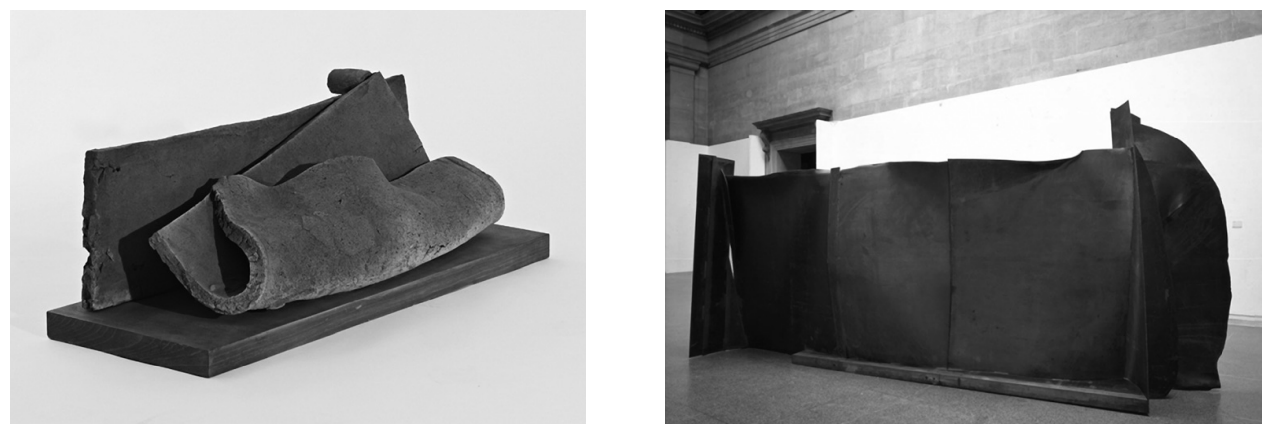


\section{AESTHETIC UTTERANCES}

The propositions which we utter to express this kind of knowledge do not share the grammar of constative propositions. Wittgenstein refers to them as expressive utterances (Äußerungen) and notes that these propositions are not intended to establish truths or represent facts. Their purpose is rather to establish a field of meaning where intimacy and community can grow. As Wittgenstein (1980) puts it, "these expressions are reactions in which people find each other." ( $\$ 874)$

Now, such an encounter and our ability, generally, to communicate with another, is dependent upon our finding some basic common ground in our understanding, in our natural reactions, in our words and gestures. It depends, as Wittgenstein (1980) would say, not upon our sharing beliefs and opinions, but primarily upon our mutual attunement in judgments, in form of life. (cf. $\$ \$ 241-2)$.

But the risk involved in such an engagement is the risk of failure, and failure despite, or in the midst of, our having made ourselves vulnerable to the other. Behind the resistance to the aesthetic may lurk not so much a justified demand for intellectual rigor, but a fear of reaching our limits, the limits of language, where, in Cavell's (1979) words, we can "begin to feel, or ought to feel terrified that maybe language (and understanding, and knowledge) rests upon very shaky foundations -a thin net over an abyss" (p. 178). Or as Nietzsche writes, driving this point home:

"Behind every cave... there is, and must necessarily be, a still deeper cave: an ampler, stranger, richer world beyond the surface, an abyss behind every bottom, beneath every 'foundation"' (Deleuze, G. and Rosalind Krauss (1983), p. 53).

In disavowing the aesthetic dimension of experience, and refusing to engage with feeling, we avoid having to come face to face with the abyss, accept our permanent uncertainty, the opacity, unruliness and unpredictability of the body, where words touch our connection to non-being, where in their limit we sense the real nature of our finitude and mortality.

\section{Philosophical Awakening}

Wittgenstein (2013) claims that the real difficulties in philosophy have to do not with the intellect but with the will. Most of all what we need, as he says, is the "resignation of feeling", "a change of attitude": 
Work on philosophy is actually closer to working on oneself. On one's own understanding. On the way one sees things, (And on what one demands of them). (p. 300)

Philosophy becomes a task of moral transformation, a search for intellectual integrity, putting thought and feeling together. Philosophy, Wittgenstein tells us, is "the battle against the bewitchment of our intelligence," i.e., a form of therapy toward lucidity. It aims at an (ethical) awakening. Our traditional resistance to aesthetics, then, is of a piece with the bewitchment of language. Instead of awakening us, marginalizing the aesthetic, just sends us to sleep.

Rather than shunning the aesthetic, philosophy must integrate it, bringing it in, just as our words must descend from the thinness of air of metaphysics, to the everyday opaqueness of the body, we must engage with our feeling and emotion. We must, in Wittgenstein's (1980) own words, "turn our investigation $180^{\circ}$ around the axis of our real need" (\$ 108).

I am not saying: if such-and-such facts of nature were different people would have different concepts (in the sense of a hypothesis). But: if anyone believes that certain concepts are absolutely the correct ones, and that having different ones would mean not realizing something that we realize -then let him imagine certain very general facts of nature to be different from what we are used to, and the formation of concepts different from the usual ones will become intelligible to him. (Wittgenstein (1980), II, xii)

In denying the emotional we are rejecting precisely this door towards awakening to the plurality and difference, the change and uncertainty that must come with our words when we start to hear them in the actual world, instead of in the metaphysics outside our language games. We must radically change our attitude towards feeling and the body, attempt to engage with the world in that way, see it through those eyes to counter that dogmatism of philosophy that can homogenize everything and abstract from the singularities of the body. "Philosophical work", Wittgenstein (2013) writes, "is actually more like work on oneself. About the way we see things. And what we expect from them." (p. 300).

\section{CODA}

Let me end with these words from Wilde's The Portrait of Dorian Gray (1996), which gives us both a diagnosis of our current situation, and a prognosis of what this change would mean for us: 
The idolatry of the senses has been frequently, and quite rightly, condemned, when men feel an instinctive and natural fear against passions and sensations stronger than themselves, and of which they are aware that they share with less organized ways of life. But it seemed to Dorian Gray that the true nature of the senses had never been understood, and that they had remained wild and animal only because the world had been determined to subdue them by starvation or kill them by suffering, instead of trying to make them elements of a new spirituality, of which a fine instinct for beauty should be a dominant feature. (p. 98)

\section{Victor I. Krebs \\ Pontificia Universidad Católica del Perú vjk5555@gmail.com}

\section{BIBLIOGRAPHY}

Alighieri, D. (2012): Vita Nova, Evanston: Northwestern University Press [transl., introd., and notes by Andrew Frisardi].

BAz, A. (2000): "What is the Point of Seeing Aspects?" Philosophical Investigations, 23: 2, April.

Cavell, S. (1979): The Claim of Reason. Wittgenstein, Skepticism, Morality and Tragedy, Oxford: Oxford University Press.

Cavell, S. (1985): Must We Mean What We Say? A Book of Essays, Cambridge, New York: Cambridge University Press.

Cavell, S. (1985a): "Music Discomposed", in Must We Mean What We Say?: A Book of Essays, Cambridge: Cambridge University Press.

Cavell, S. (1985b): "A Matter of Meaning It", in Must We Mean What We Say?: A Book of Essays, Cambridge: Cambridge University Press.

Conant, J. (1989): "An Interview with Cavell", in The Senses of Stanley Cavell, ed. Fleming, R. and M. Payne, Lewisburg: Bucknell University Press.

DAY, W. (2017): “The Aesthetic Dimension of Wittgenstein's Later Writings”, in Wittgenstein on Aesthetic Understanding, Garry Hagberg (ed.), New York: Palgrave Macmillan.

Deleuze, G., and Krauss, R. (1983): "Plato and the Simulacrum", in October, Vol 27 (Winter, 1983), pp. 45-56.

James, H. (1994): The American Scene, New York: Penguin.

McDowell, J. (1989): "Aesthetic Value, Objectivity, and the Fabric of the World," in Eva Schaper (ed.), Pleasure, Preference, and Value, Cambridge: Cambridge University Press.

PETTS, J. (2000): "Aesthetic Experience and the Revelation of Value," The Journal of Aesthetics and Art Criticism, 58:1 (Winter).

Rilke, R. M. (1989): The Selected Poetry of Rainer Maria Rilke, [Transl. Stephen Mitchell], New York: Random House, Vintage International Edition. 
Wilde, O. (1996): The Picture of Dorian Gray, in: The Complete Oscar Wilde, New York: Quality paperback Book Club.

Wittgenstein, L. (1968): Philosophical Investigations, Oxford: Basil \& Blackwell.

Wittgenstein, L. (1980): Remarks on the Philosophy of Psychology, vol. 1, Chicago: Chicago University Press.

Wittgenstein, L. (2013): The Big Typescript TS 213, German English Scholars' Edition, ed./ transl. Grant Luckhardt, C. Grant \& Maximilian A.E. Aue, Wiley-Blackwell. 